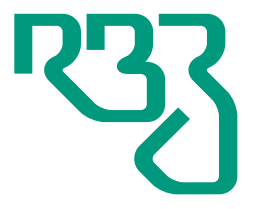

\section{Revista}

Brasileira de

Zootecnia

Brazilian Journal of Animal Science

ISSN 1806-9290

www.rbz.org.br

\title{
Feeding systems and tocopherol level in the diet and their effects on the quality of lamb meat: a meta-analysis
}

\author{
Viviane da Silva Hampel ${ }^{1}$ (iD), Cesar Henrique Espírito Candal Poli ${ }^{1 *}$ (iD, \\ Thais Devincenzi ${ }^{1}$ (iD), Luciana Pötter ${ }^{2}$ (iD \\ ${ }^{1}$ Universidade Federal do Rio Grande do Sul, Departamento do Zootecnia, Porto Alegre, \\ RS, Brasil. \\ ${ }^{2}$ Universidade Federal de Santa Maria, Departamento de Zootecnia, Santa Maria, RS, Brasil.
}

\author{
*Corresponding author: \\ cesar.poli@ufrgs.br \\ Received: September 5, 2018 \\ Accepted: April 22, 2019 \\ How to cite: Hampel, V. S.; Poli, C. H. E. C.; \\ Devincenzi, T. and Pötter, L. 2019. Feeding \\ systems and tocopherol level in the diet and \\ their effects on the quality of lamb meat: a \\ meta-analysis. Revista Brasileira de Zootecnia \\ 48:e20180223. \\ https://doi.org/10.1590/rbz4820180223 \\ Copyright: This is an open access article \\ distributed under the terms of the \\ Creative Commons Attribution License \\ (http://creativecommons.org/licenses/by/4.0/) \\ which permits unrestricted use, distribution, \\ and reproduction in any medium, provided the \\ original work is properly cited.
}

\begin{abstract}
The objective of the present study was to evaluate, through a metaanalysis, the effects of feeding systems and tocopherol levels found in the diet of lambs on qualitative characteristics of their meat. A search of the computerised literature in Science Direct databases, PubMed, Scopus, and SciELO virtual library was carried out to select works that evaluated the quality of lamb meat. As a first requirement for inclusion in the meta-analysis, articles were selected with the keywords "tocopherol", "meat", and "lamb". The variables extracted from the articles were classified according to the type of feeding system and tocopherol level in the diet of lambs. Production systems alter the qualitative characteristics of meat. Lambs raised exclusively on pasture present a higher tocopherol concentration in their meat, a lower omega 6:omega 3 ratio, a lower omega 6 concentration, and a higher conjugated linoleic acid concentration. Regardless of the dietary systems, when we classify the tocopherol levels of lamb diet, the tocopherol concentration and fatty acid level are altered by tocopherol levels in the diet. The lower tocopherol level in the diet results in meat with lower tocopherol concentration and with greater propensity to lipid oxidation.
\end{abstract}

Keywords: antioxidant, concentrated, omega 3, oxidative stress, pasture

\section{Introduction}

The search for healthier foods with a longer shelf life has attracted the interest of both consumers and the food industry. Due to the behavioural modifications of the consumer population, the offer of products considered as healthy has led several researchers to try to manipulate the composition of foods, especially those related to cardiac problems (Ítavo et al., 2016). Extending the shelf life of meat by delaying oxidative deterioration is an important goal in the meat supply chain (Luciano et al., 2009).

The search for healthier foods has led researchers in meat science to characterise the lipid profile of these foods. Shelf life attributes, such as colour stability and oxidation of meat fatty acids, are influenced by the composition of muscle tissues, which, in turn, are governed by antioxidant capacity, haem pigment (haem iron) concentration, and lipid concentration and composition found in muscles. All these characteristics are linked to the feed given to animals (Papuc et al., 2017; Luciano et al., 2009).

Tocopherol is an antioxidant that plays an important role as an inhibitor of the oxidation of free radicals and makes it retarding to convert unsaturated fatty acids into aldehydes (Lobo et al., 2010). These reactions result in changes in colour and loss of taste and nutritional value, thus limiting the shelf life of the meat (Luzia and Jorge, 2009). The addition of tocopherol to diet of lambs, via either 
pasture or supplementation, may maintain the desirable red colour of the meat in nature on display at a retail store. The protective effect of tocopherol is exerted by retarding the oxidation of the oxymyoglobin pigment and inhibiting the oxidation of polyunsaturated fatty acids (PUFA) (González-Calvo et al., 2015).

Previous studies have reported the benefits of tocopherol in the quality and maintenance of lamb meat quality. However, not all studies evaluate the variables associated with meat quality within the scope of tocopherol level in the diet and types of diet. Therefore, it is important to carry out a study to assess the effects that compiles several studies to obtain novel information concerning the effects of tocopherol level and type of diet on various aspects of meat quality. In such cases, meta-analysis is a valuable tool. Thus, the objective of the present study was to evaluate the effects of feeding systems as well as tocopherol levels in the diet on qualitative characteristics of lamb meat using a meta-analysis.

\section{Material and Methods}

A literature search was conducted in multiple databases, including Science Direct, PubMed, Scopus, and SciELO virtual library, to select studies that evaluated the quality of lamb meat regarding the tocopherol content in the diet of lambs and type of feeding offered to them. This review was conducted in four stages: identification, selection, evaluation of eligibility, and inclusion, as recommended in the Preferred Reporting Items for Systematic Reviews and Meta-Analyses (PRISMA) (Moher et al., 2009) (Figure 1).

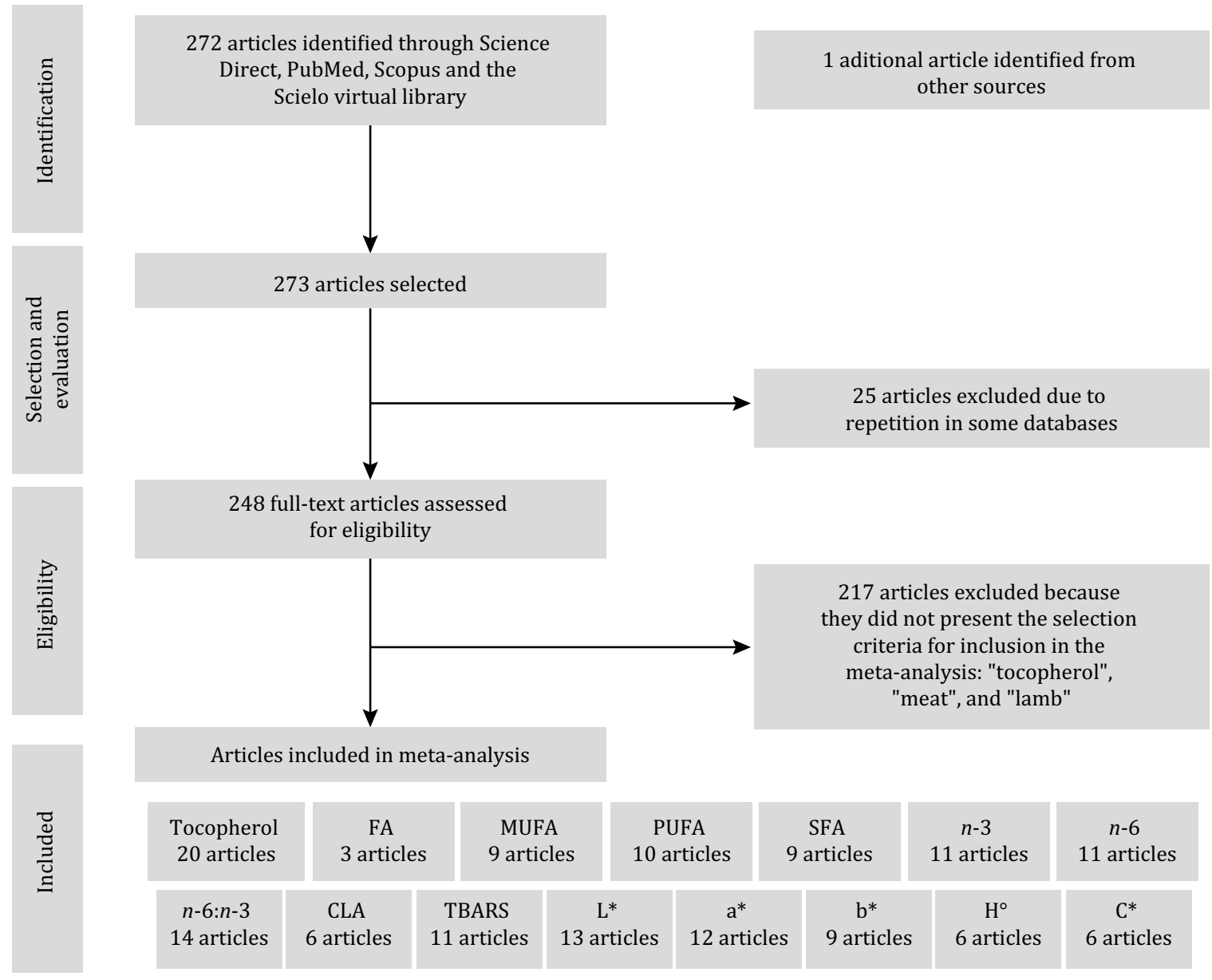

FA - total fatty acid content; MUFA - monounsaturated fatty acid content; PUFA - polyunsaturated fatty acid content; SFA - saturated fatty acid content; $n$-3 - fatty acid content of omega $3 ; n$-6- fatty acid content of omega 6 ; CLA - conjugated linoleic acid content; TBARS - thiobarbituric acid reactive substances, six days of storage; $\mathrm{L}^{*}$ - brightness; $\mathrm{a}^{*}$ - redness; $\mathrm{b}^{*}$ - yellowness; $\mathrm{H}^{\circ}$ - hue angle; $\mathrm{C}^{*}$ - chroma.

Figure 1 - PRISMA flowchart. 
Combinations of the search terms "tocopherol", "meat", and "lamb" were used in the research. The selected articles were published between 2007 and February, 2018. After the search, 272 articles were found, and the work of Turner et al. (2002), which aided in the classification of levels, described below, was also added to the database. The 25 articles were repeated in some database. After this first selection, the abstracts of these 248 articles were read, in which the first requirement for inclusion in the meta-analysis was to find the keywords "tocopherol", "meat", and "lamb". The selected papers were read in full for a second stage of selection, according to pre-defined eligibility criteria, and after this stage, 31 studies were selected for the meta-analysis.

The information extracted from articles was organised in a spreadsheet. The tocopherol concentration in the diet and types of feed offered to lambs were included in the analysis. We used variable responses extracted from the articles in the meta-analysis (Table 1). Among them are the tocopherol and fatty acid concentrations, as well as characteristics of lamb, including meat tocopherol content (Tocopherol), total fatty acid (FA) content, monounsaturated fatty acid (MUFA) content, polyunsaturated fatty acid (PUFA) content, saturated fatty acid (SFA) content, fatty acid content of omega $3(n-3)$ and omega $6(n-6)$ groups, $n-6: n-3$ ratio, conjugated linoleic acid (CLA) content, thiobarbituric acid reactive substances (TBARS) - six days of storage, brightness $\left(\mathrm{L}^{*}\right)$, redness $\left(\mathrm{a}^{*}\right)$, yellowness $\left(\mathrm{b}^{*}\right)$, hue angle $\left(\mathrm{H}^{\circ}\right)$, and chroma $\left(\mathrm{C}^{*}\right)$.

Data from the different articles were classified according to the feeding system used and tocopherol level found in the diet. In the first classification, data were grouped according to one of three types of feeding system: pasture (animals kept exclusively on pasture); concentrated (animals kept exclusively receiving some type of concentrate with a small addition of roughages); and pasture + concentrated (animals kept in the pasture or silage receiving some type of concentrate). In the second classification, data were grouped according to tocopherol levels found in the diet of lambs: level 1 (animals receiving up to $200 \mathrm{mg} \mathrm{kg}^{-1} \mathrm{DM}$ in the diet), level 2 (animals receiving 201 to $400 \mathrm{mg} \mathrm{kg}^{-1} \mathrm{DM}$ ), and level 3 (animals receiving above $400 \mathrm{mg} \mathrm{kg}^{-1} \mathrm{DM}$ tocopherol in their diet). The classification of tocopherol levels in lamb diet was based on the work of Turner et al. (2002), who reported that tocopherol levels above $400 \mathrm{mg} \mathrm{kg}^{-1}$ reach a plateau, and more tocopherol is not accumulated in the meat. Therefore, we used levels up to $400 \mathrm{mg} \mathrm{kg}^{-1}$ as an intermediate level and included a level above (more than $400 \mathrm{mg} \mathrm{kg}^{-1}$ ) and another below (up to $200 \mathrm{mg} \mathrm{kg}^{-1}$ ).

The analyses were made according to the following general mathematical model:

$$
\gamma \mathrm{ijk}=\mu+\mathrm{Ti}+\mathrm{aj}+\varepsilon \mathrm{ijk},
$$

in which $\gamma \mathrm{ijk}=$ dependent variables, $\mu=$ mean of all observations, $\mathrm{Ti}=$ fixed effect of feeding systems or tocopherol levels, aj = random effect of articles, and $\varepsilon i j \mathrm{k}=$ random residual error.

After the normality test of the residues, a variance analysis was performed using the MIXED procedure in the SAS program (Statistical Analysis System, version 9.4). A test of selection of structures was made using the Bayesian information criterion, from which the structure "variance component" (VC) was selected. When differences were observed, the means were compared using the LSmeans. The significance was established at P-value $=0.05$, whereas probability values between 0.05 and 0.10 were considered as tendency. In addition, Pearson correlation analysis as well as multiple regression using the STEPWISE procedure (Forward $=0.05$ ) were also conducted. The variables CLA and omega $n$-6:omega $n-3$ ratio were transformed via $\log ^{10}$, because they did not show normality. For the variables $\mathrm{b}^{*}, \mathrm{H}^{\circ}$, and $\mathrm{C}^{*}$ of colour, we only performed the comparison between pasture and concentrate, by the absence of values for the mixed classification (concentrate + pasture). For the variable $b^{*}$ of colour, when compared with tocopherol levels, we only performed the comparison between level 1 and level 3 , due to the absence of values for the intermediate level (level 2).

\section{Results}

Grazing, as an option for increasing $\alpha$-tocopherol of muscle of lambs kept exclusively on pasture, is $38.04 \%$ higher compared with the other feeding systems $\left(2.54 \mathrm{mg} \mathrm{kg}^{-1}\right.$; Table $\left.2 ; \mathrm{P}<0.05\right)$. The proportion 
Table 1 - Description of the primary studies included in the meta-analysis

\begin{tabular}{|c|c|c|c|}
\hline Study ${ }^{1}$ & Country & Feeding system & Observed variable \\
\hline Álvarez et al., 2014 & Spain & $\begin{array}{c}\text { Concentrated } \\
\text { Pasture }\end{array}$ & $L^{*}, a^{*}, b^{*}, C^{*}$ \\
\hline Bellés et al., 2018 & Spain & $\begin{array}{c}\text { Concentrated } \\
-\end{array}$ & Tocopherol, MUFA, PUFA, SFA, $n-6, n-3, n-6: n-3$ \\
\hline Berthelot et al., 2014 & France & $\begin{array}{c}\text { Concentrated } \\
-\end{array}$ & FA, MUFA, SFA, $n-6, n-3, n-6: n-3$, CLA \\
\hline Bhatt et al., 2015 & India & $\begin{array}{c}\text { Concentrated } \\
\text { Pasture }\end{array}$ & MUFA, PUFA, SFA, $n-6: n-3$, CLA, TBARS \\
\hline Brito et al., 2017 & Australia & $\begin{array}{c}- \\
\text { Pasture }\end{array}$ & Tocopherol, $n-6: n-3$, TBARS \\
\hline González-Calvo et al., 2014 & Spain & $\begin{array}{c}\text { Concentrated } \\
-\end{array}$ & $\begin{array}{l}\text { Tocopherol, MUFA, PUFA, SFA, } n-6, n-3, n-6: n-3 \text {, TBARS, } \\
\text { CLA, } \mathrm{L}^{*}, \mathrm{a}^{*}, \mathrm{~b}^{*}\end{array}$ \\
\hline D’Alessandroa et al., 2012 & Italy & $\begin{array}{c}\text { Concentrated } \\
\text { Pasture }\end{array}$ & Tocopherol, TBARS \\
\hline Hopkins et al., 2013 & Australia & Pasture & Tocopherol \\
\hline Jose et al., 2016 & Australia & $\begin{array}{c}\text { Concentrated } \\
\text { Pasture }\end{array}$ & Tocopherol \\
\hline Kasapidou et al., 2012 & $\begin{array}{l}\text { United } \\
\text { Kingdon }\end{array}$ & $\begin{array}{c}\text { Concentrated } \\
\text { Pasture }\end{array}$ & Tocopherol, $n-6, n-3, n-6: n-3$, TBARS, CLA \\
\hline Lee et al., 2007 & United States & $\begin{array}{c}\text { Concentrated } \\
-\end{array}$ & Tocopherol \\
\hline Liu et al., 2013 & China & $\begin{array}{c}\text { Concentrated } \\
\text { - }\end{array}$ & Tocopherol, MUFA, PUFA, SFA, $n-6, n-3, n-6: n-3$ \\
\hline Lobón et al., 2017 & Spain & $\begin{array}{c}\text { Concentrated } \\
\text { Pasture }\end{array}$ & Tocopherol, $\mathrm{L}^{*}, \mathrm{a}^{*}, \mathrm{~b}^{*}, \mathrm{H}^{\circ}, \mathrm{C}^{*}$ \\
\hline Milewski et al., 2014 & Poland & - & Tocopherol, FA, MUFA, PUFA, SFA, $n-6, n-3, n-6: n-3$, CLA \\
\hline Morán et al., 2012a & Spain & $\begin{array}{c}\text { Concentrated } \\
-\end{array}$ & $L^{*}, a^{*}, b^{*}$ \\
\hline Morán et al., 2012b & Spain & $\begin{array}{c}\text { Concentrated } \\
-\end{array}$ & TBARS \\
\hline Morán et al., 2013 & Spain & $\begin{array}{c}\text { Concentrated } \\
-\end{array}$ & MUFA, PUFA, SFA, $n-6, n-3, n-6: n-3$, CLA \\
\hline Muela et al., 2014 & Spain & $\begin{array}{c}\text { Concentrated } \\
-\end{array}$ & TBARS, $\mathrm{L}^{*}, \mathrm{H}^{\circ}, \mathrm{C}^{*}$ \\
\hline Muíño et al., 2014 & Spain & $\begin{array}{c}\text { Concentrated } \\
-\end{array}$ & Tocopherol, MUFA, PUFA, SFA, $n-6, n-3, n-6: n-3$, TBARS \\
\hline Ortuño et al., 2015 & Spain & $\begin{array}{c}\text { Concentrated } \\
-\end{array}$ & TBARS, $\mathrm{L}^{*}, \mathrm{a}^{*}, \mathrm{H}^{\circ}, \mathrm{C}^{*}$ \\
\hline Petron et al., 2007 & Belgium & Pasture & Tocopherol, TBARS, $\mathrm{L}^{*}, \mathrm{a}^{*}, \mathrm{~b}^{*}$ \\
\hline Ponnampalam et al., 2012a & Australia & Pasture & Tocopherol, FA, PUFA, $n-6, n-3, n-6: n-3$, TBARS \\
\hline
\end{tabular}


Table 1 (Continued)

\begin{tabular}{|c|c|c|c|}
\hline Ponnampalam et al., 2012b & Australia & $\begin{array}{l}\text { Concentrated } \\
\text { Pasture }\end{array}$ & Tocopherol, PUFA, $n-6, n-3, n-6: n-3$, a* \\
\hline Ponnampalama et al., 2016 & Australia & $\begin{array}{c}\text { Concentrated } \\
\text { Pasture }\end{array}$ & Tocopherol, $n-6: n-3$ \\
\hline Ripoll et al., 2011 & Spain & $\begin{array}{c}\text { Concentrated } \\
\text { Pasture }\end{array}$ & TBARS, $\mathrm{L}^{*}, \mathrm{H}^{\circ}$ \\
\hline Ripoll et al., 2013 & Spain & $\begin{array}{c}\text { Concentrated } \\
\text { Pasture }\end{array}$ & Tocopherol, TBARS, $\mathrm{L}^{*}, \mathrm{a}^{*}, \mathrm{~b}^{*}, \mathrm{H}^{\circ}, \mathrm{C}^{*}$ \\
\hline Sales et al., 2013 & Brazil & $\begin{array}{c}\text { Concentrated } \\
-\end{array}$ & $L^{*}, a^{*}, b^{*}$ \\
\hline Simitzis et al., 2013 & Greece & $\begin{array}{c}\text { Concentrated } \\
-\end{array}$ & FA, L*, a* \\
\hline Turner et al., 2002 & United States & $\begin{array}{c}\text { Concentrated } \\
\text { Pasture }\end{array}$ & Tocopherol \\
\hline Vieira et al., 2012 & Spain & $\begin{array}{c}\text { Concentrated } \\
-\end{array}$ & $\begin{array}{l}\text { Tocopherol, MUFA, PUFA, SFA, } n-6, n-3, n-6: n-3 \text {, TBARS, } \\
\qquad L^{*}, a^{*}, b^{*}\end{array}$ \\
\hline Yagoubia et al., 2018 & Tunisia & $\begin{array}{c}\text { Concentrated } \\
-\end{array}$ & Tocopherol, $n-6: n-3$, TBARS, $\mathrm{L}^{*}, \mathrm{a}^{*}, \mathrm{~b}^{*}, \mathrm{H}^{\circ}, \mathrm{C}^{*}$ \\
\hline
\end{tabular}

FA - total fatty acid content; MUFA - monounsaturated fatty acid content; PUFA - polyunsaturated fatty acid content; SFA - saturated fatty acid content; $n$-3 - fatty acid content of omega $3 ; n-6$ - fatty acid content of omega 6 ; CLA - conjugated linoleic acid content; TBARS - thiobarbituric acid reactive substances, six days of storage; $\mathrm{L}^{*}$ - brightness; $\mathrm{a}^{*}$ - redness; $\mathrm{b}^{*}$ - yellowness; $\mathrm{H}^{\circ}$ - hue angle; $\mathrm{C}^{*}$ - chroma.

${ }^{1}$ List of references used for the meta-analysis and the variable responses extracted from the articles.

of forage in the diet of lambs receiving concentrate + pasture was not sufficient to alter the deposition of tocopherol in their meat (Table 2; $\mathrm{P}>0.05$ ).

There were no significant differences $(\mathrm{P}>0.05)$ among type of feeding systems on the groups of FA according to saturation degree (Table 2). Type of feeding systems only affected MUFA, $n-6$, and $n-6: n-3$ $(\mathrm{P}<0.05$; Table 2). Lambs from the pasture feeding systems had meat with less $n-6$ and lower $n-6: n-3$ ratio (Table 2). Lambs from the pasture + concentrated feeding systems had meat with greater MUFA $(\mathrm{P}<0.05$; Table 2).

The inclusion of pasture in the diet of lambs influences the CLA concentration in the meat (Table 2). Lambs of pasture or pasture + concentrated systems showed a proportion of CLA that was three times higher $(\mathrm{P}<0.05$; Table 2 ) than lambs consuming exclusively concentrated.

Lipid peroxidation of meat is measured by the content of TBARS. There were no significant differences $(\mathrm{P}>0.05)$ among type of feeding systems on TBARS, with a mean of $0.48 \mathrm{mg}$ of malonaldehyde $\mathrm{kg}^{-1}$ (Table 2). The lambs of pasture feeding systems presented greater $L^{*}$ and $b^{*}$ values $(P<0.05)$, and a tendency of greater of $\mathrm{C}^{*}$ value $(\mathrm{P}=0.0840)$ in the meat, when compared with the other feeding systems (Table 2).

Meta-analysis showed that the tocopherol content of the feeding has an influence on the tocopherol content in lamb. This influence may be affected by the different tocopherol levels found in the feeding systems. As expected, the tocopherol content in lamb meat is lower when the dietary content is less than $200 \mathrm{mg} \mathrm{kg}^{-1} \mathrm{DM}$ (level 1; Table 3). However, when tocopherol levels in the feed are above $400 \mathrm{mg} \mathrm{kg}^{-1} \mathrm{DM}$, there is no significant increase in the concentration of alpha-tocopherol in the meat. The highest tocopherol concentration in the diet was observed at level 2 (200 to $400 \mathrm{mg} \mathrm{kg}^{-1} \mathrm{DM}$; Table 3).

Most of the FA groups according to the degree of saturation were not affected by tocopherol level in the diet (Table 3). The tocopherol level only affected the FA and MUFA $(\mathrm{P}<0.05$; Table 3$)$. The FA content 
Table 2 - Attributes of meat of lambs from different feeding systems

\begin{tabular}{|c|c|c|c|c|c|c|}
\hline \multirow{2}{*}{ Variable } & \multicolumn{3}{|c|}{ Feeding system } & \multirow{2}{*}{$\mathrm{P}^{1}$} & \multirow{2}{*}{$\mathrm{SE}$} & \multirow{2}{*}{$\mathrm{n}^{2}$} \\
\hline & Pasture & Concentrated & Pasture + concentrated & & & \\
\hline $\begin{array}{l}\text { Alpha-tocopherol } \\
\left(\mathrm{mg} \mathrm{kg}^{-1}\right)\end{array}$ & $4.10 \mathrm{a}$ & $2.45 b$ & $2.63 b$ & 0.0003 & 0.25 & 67 \\
\hline FA (\%) & 43.85 & 37.88 & 44.17 & 0.6828 & 4.47 & 14 \\
\hline SFA (\%) & 51.98 & 46.27 & 42.01 & 0.4400 & 4.53 & 31 \\
\hline MUFA (\%) & $41.33 b$ & $41.55 b$ & $48.34 a$ & 0.0260 & 2.95 & 31 \\
\hline PUFA (\%) & 5.70 & 6.23 & 7.65 & 0.5040 & 1.35 & 34 \\
\hline$n-6(\%)$ & $2.52 b$ & $6.14 \mathrm{a}$ & $4.02 \mathrm{ab}$ & 0.0431 & 1.15 & 41 \\
\hline$n-3(\%)$ & 1.23 & 1.52 & 0.83 & 0.2904 & 0.35 & 41 \\
\hline$n-6: n-3$ & $1.88 \mathrm{~b}$ & $5.71 \mathrm{a}$ & $4.84 \mathrm{a}$ & 0.0003 & 0.74 & 53 \\
\hline CLA & $0.85 a$ & $0.24 \mathrm{~b}$ & $0.76 \mathrm{a}$ & 0.0118 & 0.15 & 22 \\
\hline $\begin{array}{l}\text { TBARS (mg of } \\
\text { malonaldehyde } \mathrm{kg}^{-1} \text { ) }\end{array}$ & 0.23 & 0.94 & 0.29 & 0.1241 & 0.35 & 51 \\
\hline $\mathrm{L}^{*}$ & $58.77 \mathrm{a}$ & $43.16 \mathrm{~b}$ & $31.32 \mathrm{c}$ & 0.0005 & 4.65 & 38 \\
\hline$a^{*}$ & 10.33 & 9.34 & 12.40 & 0.1553 & 1.54 & 30 \\
\hline $\mathrm{b}^{*}$ & $15.04 \mathrm{a}$ & $10.90 \mathrm{~b}$ & - & 0.0001 & 0.51 & 21 \\
\hline $\mathrm{H}^{\circ}$ & 51.70 & 35.18 & - & 0.3666 & 12.31 & 18 \\
\hline $\mathrm{C}^{*}$ & 15.63 & 13.13 & - & 0.0840 & 0.91 & 16 \\
\hline
\end{tabular}

FA - total fatty acid content; MUFA - monounsaturated fatty acid content; PUFA - polyunsaturated fatty acid content; SFA - saturated fatty acid content; $n$-3 - fatty acid content of omega 3; $n$ - 6 - fatty acid content of omega 6; CLA - conjugated linoleic acid content; TBARS - thiobarbituric acid reactive substances, six days of storage; $\mathrm{L}^{*}$ - brightness; $\mathrm{a}^{*}$ - redness; $\mathrm{b}^{*}$ - yellowness; $\mathrm{H}^{\circ}$ - hue angle; $\mathrm{C}^{*}$ - chroma; $\mathrm{SE}$ - standard error. ${ }^{1}$ Probability.

${ }^{2}$ Number of repetitions.

a,b - Values within a row with different letters differ significantly at $\mathrm{P}<0.05$.

For the variables yellowness $\left(\mathrm{b}^{*}\right)$, hue angle $\left(\mathrm{H}^{\circ}\right)$, and chroma $\left(\mathrm{C}^{*}\right)$ of colour, when compared to feeds, we only have the comparison between pasture and concentrate, by absence of values for the mixed classification (concentrate + pasture).

Table 3 - Attributes of lamb meat for three tocopherol levels in the diet

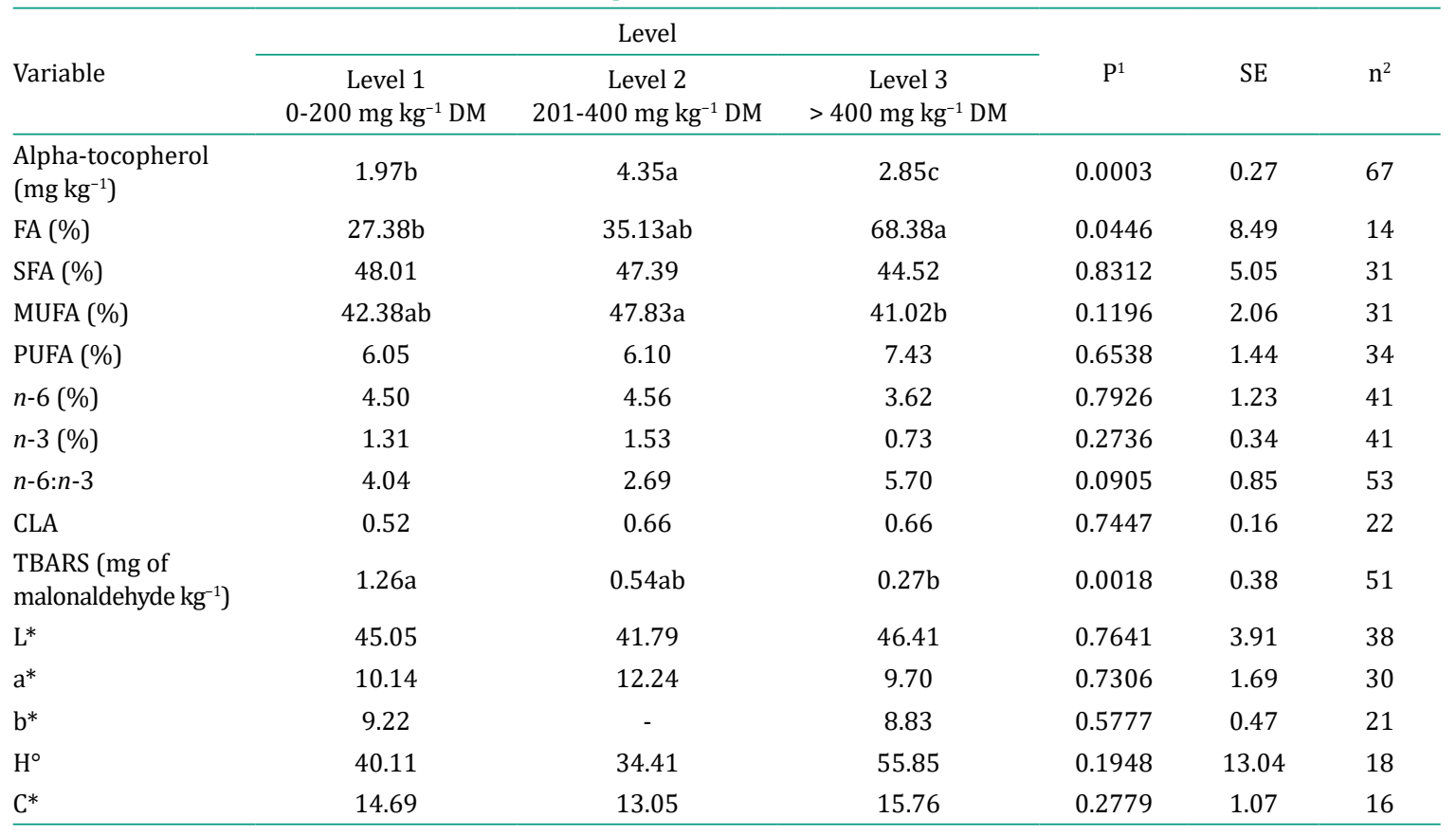

FA - total fatty acid content; MUFA - monounsaturated fatty acid content; PUFA - polyunsaturated fatty acid content; SFA - saturated fatty acid content; $n$-3 - fatty acid content of omega 3; $n$ - 6 - fatty acid content of omega 6; CLA - conjugated linoleic acid content; TBARS - thiobarbituric acid reactive substances, six days of storage; $\mathrm{L}^{*}$ - brightness; $\mathrm{a}^{*}$ - redness; $\mathrm{b}^{*}$ - yellowness; $\mathrm{H}^{\circ}$ - hue angle; $\mathrm{C}^{*}$ - chroma; SE - standard error.

${ }^{1}$ Probability.

${ }^{2}$ Number of repetitions.

a,b - Values within a row with different letters differ significantly at $\mathrm{P}<0.05$.

For the variable yellowness ( $\mathrm{b}^{*}$ ) of colour, when compared to tocopherol levels, we only have the classification between level 1 and level 3 , due to the absence of values for the intermediate level (level 2). 
in lamb meat increases as the tocopherol levels ingested by lambs in the diet increase; the highest FA content was observed when the animals received supplementation with more than $400 \mathrm{mg} \mathrm{kg}^{-1}$ DM (level 3; Table 3). The lambs from the level $2\left(201-400 \mathrm{mg} \mathrm{kg}^{-1} \mathrm{DM}\right)$ had greater MUFA ( $\mathrm{P}<0.05$; Table 3). That could be related to the higher tocopherol concentration of meat (Table 3), which could prevent oxidation of two MUFA.

The lipid oxidation, measured as TBARS, was significantly altered by the tocopherol level in the diet $(\mathrm{P}<0.05$; Table 3). We observed a correlation between decreasing TBARS and increasing tocopherol dose in the diet $(\mathrm{P}=0.0022 ; \mathrm{r}=-0.41)$. The tocopherol level in diet did not affect the colour variables of meat $(\mathrm{P}>0.05$; Table 3$)$.

\section{Discussion}

Grazing is an option for increasing alpha-tocopherol muscle content, as green forages are rich in this compound (Ripoll et al., 2013; Jose et al., 2016). The type of tocopherol that the feeding system made available may have been related to the tocopherol concentration in lamb meat because, according to Ponnampalam et al. (2012a), who kept the lambs in a perennial pasture or in an annual pasture and fed a concentrated diet, a higher alpha-tocopherol concentration was found in the muscle of lambs kept in the perennial pasture. This result is because animals in perennial pastures ingested greater amounts of alpha-tocopherol and lambs kept in the annual pasture in senescence and received the concentrated diet ingested more gamma-tocopherol. The alpha-tocopherol form is most prevalent in different tissues of animals and humans. In fact, there is a preference for the absorption of alpha-tocopherol in relation to gamma-tocopherol in the peripheral system of the body (Ponnampalam et al., 2012a).

The pasture + concentrated feeding systems resulted in lamb meat with greater MUFA concentration, because there may have been a higher rate of passage of these fatty acids through the rumen with the mixed feed, and also because they are less prone to lipid oxidation (Díaz et al., 2011).

The lower values of $n-6$ fatty acids in the meat of lambs fed in pasture systems may be related to a lower concentration of this lipid in plants, and consequently, a lower accumulation of intramuscular lipids in animals (Popova et al., 2015). The ability of PUFA to be incorporated into phospholipids is limited, and $n-6$ fatty acids compete more efficiently than $n-3$ fatty acids (Wood et al., 2008). The $n-6: n-3$ ratio in the meat of lambs raised exclusively on pasture (1.88) is within the limits recommended by Simopoulos (2002), 4:1, to be beneficial to human health.

The inclusion of pasture in the feeding of lambs improves the proportion of CLA in meat. Boughalmi and Araba (2016), working with three feeding systems, also found that grazing animals, with or

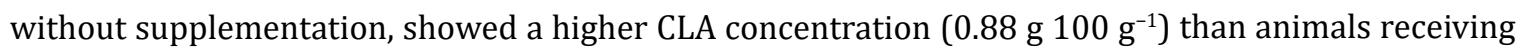

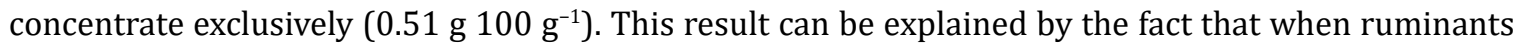
consume pasture, it includes PUFA, which are later biohydrogenated in the rumen and transformed into vaccenic acids, which are later the precursor to CLA (Hajji et al., 2016). The CLA concentration provides benefits to human health (Salter and Tapper, 2013).

In this meta-analysis, it was found that the $n-6$ concentration in the diet was the main cause of the variation of $n-6: n-3$ ratio in lamb meat. There was no effect of dietary systems on the concentration of omega-3 (n-3) family of fatty acids (Table 2), which contradicts trends that have been reported in the literature and indicates that there is a higher $n-3$ concentration in meat of ruminant animals when they are fed exclusively on pasture (Cividini et al., 2014). This disagrees with previous reports that indicate that there is a higher $n-3$ concentration in meat of ruminant animals fed exclusively on grazing-based systems.

The stability of fatty acid oxidation of meat is influenced by the composition of muscle tissues, which is tightly related to feed offered (Daley et al., 2010). Hajji et al. (2016) found an important effect of feeding system on lipid oxidation. Animals kept on pasture showed lower TBARS concentrations. Popova et al. 
(2015) worked with data from a meta-analysis and also did not find a significant effect of feeding system on the total lipid content.

Pasture systems change the colouring of lamb meat. Atti et al. (2013), working with lambs, also found higher values of $b^{*}$ in the colouration of meat of lambs grazing vs. those fed concentrate. Grazing animals consume a greater proportion of antioxidants that contribute to increases in the haeminic pigments, changing the colour and brightness of lamb meat (Costa et al., 2011). The darker colouration of the meat of grazing animals can be related to the increase of myoglobin in the muscle, justified by the greater physical activity of these animals (Perlo et al., 2008).

The tocopherol content of meat may have an absorption limit to the inclusion of tocopherol in the diet with an effect on the tocopherol concentration in the muscle. This result was also found by Turner et al. (2002) who, working with different alpha-tocopherol levels in the diet, found a quadratic equation regarding dose and muscle concentration. They reported that a plateau occurs where the highest tocopherol concentration in the diet occurred when the animals received $403 \mathrm{mg} \mathrm{kg}^{-1} \mathrm{DM}$. However, the duration of dietary supplementation may influence the deposition of alpha-tocopherol. In general, higher tocopherol content in the diet or longer supplementation time are associated with higher tocopherol concentrations in the meat (Ripoll et al., 2013).

The higher tocopherol level in the diet resulted in higher FA concentration in the meat. Berthelot et al. (2014), working with levels similar to those found in this analysis, reported that when lambs received the highest tocopherol levels in the diet, they tended to have a higher FA concentration in the muscle.

The level 2 of tocopherol in diet resulted in a meat with greater MUFA. Liu et al. (2013), working with different tocopherol supplementation levels in the diet, stated that there is an effect of tocopherol levels in the diet of lambs in MUFA, PUFA, and SFA concentrations in the meat. In our review, the meta-analysis shows that dietary tocopherol levels do not influence PUFA and SFA concentrations.

The meta-analysis shows that there is no significant effect of tocopherol levels on omega- 6 and omega- 3 concentrations, and on the $n-6: n-3$ ratio in meat $(\mathrm{P}>0.05$; Table 3$)$. Because tocopherol is mainly present in green pastures and that grass-fed animals have a lower $n-6: n-3$ ratio than animals fed concentrate, it was expected that the tocopherol in the diet could influence the omega- 6 and omega-3 levels (Mapiye et al., 2012). However, this variation of the unsaturated fatty acids is influenced by different factors, among them the finishing of the animal. Due to the different variations that occurred between the studies, it was not possible to determine the differences between tocopherol levels.

Although the CLA content was influenced by feeding system to which the lambs were subjected (Table 2), the CLA content is not associated with the tocopherol concentration in the diet $(\mathrm{P}>0.05$; Table 3). Although there was a higher tocopherol concentration in the pasture, this did not influence in an effective manner to improve the amount of CLA in the meat. Even though CLA is primarily a product of ruminant animals, produced from bacteria present in their ruminal environment, and since the tocopherol level does not alter ruminal bacteria, the CLA content was similar between levels (Table 3).

The lipid oxidation decreases with increasing tocopherol dose (Kasapidou et al., 2009). Even though the level of lipid oxidation at level 1 showed the highest TBARS concentration, this value only exceeded slightly the accepted threshold value of $1 \mathrm{mg} \mathrm{MDA} \mathrm{kg}^{-1}$ in meat (Ripoll et al., 2011).

The tocopherol level in the diet did not affect meat colour. Ripoll et al. (2013) used different doses on different days with $500 \mathrm{mg}$ tocopherol day ${ }^{-1}$ and found no difference in colour. This result shows that tocopherol in the diet does not affect the colouring of the meat. All lambs displayed average $\mathrm{L}^{*}$ values of 40, indicating a light-coloured and acceptable meat (Hajji et al., 2016).

R. Bras. Zootec., 48:e20180223, 2019 


\section{Conclusions}

Feeding systems alter the qualitative characteristics of meat. Lambs exclusively raised on pasture present higher tocopherol concentrations, lower omega-6:omega-3 ratio, lower omega 6, and higher conjugated linoleic acid concentration in their meat. Regardless of dietary systems, tocopherol levels alter the tocopherol concentration in meat. The lower tocopherol level in the diet results in a meat with lower tocopherol concentration and with greater propensity to lipid oxidation.

\section{Conflict of Interest}

The authors declare no conflict of interest.

\section{Author Contributions}

Conceptualization: V.S. Hampel, C.H.E.C. Poli, T. Devincenzi and L. Pötter. Data curation: V.S. Hampel and L. Pötter. Formal analysis: V.S. Hampel, T. Devincenzi and L. Pötter. Investigation: V.S. Hampel, C.H.E.C. Poli, T. Devincenzi and L. Pötter. Methodology: V.S. Hampel, T. Devincenzi and L. Pötter. Project administration: V.S. Hampel and C.H.E.C. Poli. Supervision: C.H.E.C. Poli, T. Devincenzi and L. Pötter. Writing-original draft: V.S. Hampel. Writing-review \& editing: V.S. Hampel, C.H.E.C. Poli and L. Pötter.

\section{Acknowledgments}

We would like to thank the Conselho Nacional de Desenvolvimento Científico e Tecnológico (CNPq), for the doctorate scholarship to the first author, and Coordenação de Aperfeiçoamento de Pessoal de Nível Superior (CAPES), for the PhD sandwich scholarship to the first author (process number: PDSE 88881.132015/2016-01).

\section{References}

Álvarez, R.; Meléndez-Martínez, A. J.; Vicario, I. M. and Alcalde, M. J. 2014. Effect of pasture and concentrate diets on concentrations of carotenoids, vitamin A and vitamin $\mathrm{E}$ in plasma and adipose tissue of lambs. Journal of Food Composition and Analysis 36:59-65. https://doi.org/10.1016/j.jfca.2014.08.001

Atti, N.; Labidi, J. and Mahouachi, M. 2013. Effects of feeding system and Acacia cyanophylla-condensed tannins on lamb growth and meat characteristics. Options Méditerranéennes série A 107:177-181.

Bellés, M.; Leal, L. N.; Díaz, V.; Alonso, V.; Roncalés, P. and Beltrán, J. A. 2018. Effect of dietary vitamin E on physicochemical and fatty acid stability of fresh and thawed lamb. Food Chemistry 239:1-8. https://doi.org/10.1016/j. foodchem.2017.06.076

Berthelot, V.; Broudiscou, L. and Schmidely, P. 2014. Effect of vitamin E supplementation on fatty acid composition of muscle and adipose tissues of indoor lambs with special attention on rumen-derived trans monounsaturated fatty acids. Meat Science 96:1281-1288. https://doi.org/10.1016/j.meatsci.2013.10.026

Bhatt, R. S.; Sahoo, A.; Karim, S. A. and Agrawal, A. R. 2015. Effects of calcium soap of rice bran oil fatty acids supplementation alone and with DL- $\alpha$-tocopherol acetate in lamb diets on performance, digestibility, ruminal parameters and meat quality. Journal of Animal Physiology and Animal Nutrition 100:578-589. https://doi.org/10.1111/jpn.12370

Boughalmi, A. and Araba, A. 2016. Effect of feeding management from grass to concentrate feed on growth, carcass characteristics, meat quality and fatty acid profile of Timahdite lamb breed. Small Ruminant Research 144:158-163.

Brito, G. F.; Holman, B. W. B.; McGrath, S. R.; Friend, M. A.; van de Ven, R. and Hopkins, D. L. 2017. The effect of forage-types on the fatty acid profile, lipid and protein oxidation, and retail colour stability of muscles from White Dorper lambs. Meat Science 130:81-90. https://doi.org/10.1016/j.meatsci.2017.04.001

Castagnara, D. D.; Zoz, T.; Krutzmann, A.; Uhlein, A.; Mesquita, E. E.; Neres, M. A. and Oliveira, P. S. R. 2011. Produção de forragem, características estruturais e eficiência de utilização do nitrogênio em forrageiras tropicais sob adubação nitrogenada. Semina: Ciências Agrárias 32:1637-1647.

Cividini, A.; Levart, A.; Žgur, S. and Kompan, D. 2014. Fatty acid composition of lamb meat from the autochthonous Jezersko-Solčava breed reared in different production systems. Meat Science 97:480-485. https://doi.org/10.1016/j. meatsci.2013.12.012

R. Bras. Zootec., 48:e20180223, 2019 
Costa, P.; Costa, A. F.; Lopes, P. A.; Alfaia, C. M.; Bessa, R. J. B.; Roseiro, L. C. and Prates, J. A. M. 2011. Fatty acid composition, cholesterol and $\alpha$-tocopherol of Barrosã-PDO veal produced in farms located in lowlands, ridges and mountains. Journal of Food Composition and Analysis 24:987-994. https://doi.org/10.1016/j.jfca.2010.11.008

D’Alessandro, A. G.; Maiorano, G.; Kowaliszyn, B.; Loiudice, P. and Martemucci, G. 2012. How the nutritional value and consumer acceptability of suckling lambs meat is affected by the maternal feeding system. Small Ruminant Research 106:83-91. https://doi.org/10.1016/j.smallrumres.2012.02.001

Daley, C. A.; Abbott, A.; Doyle, P. S.; Nader, G. A. and Larson, S. 2010. A review of fatty acid profiles and antioxidant content in grass-fed and grain-fed beef. Nutrition Journal 9:10. https://doi.org/10.1186/1475-2891-9-10

Díaz, M. T.; Cañeque, V.; Sánchez, C. I.; Lauzurica, S.; Pérez, C.; Fernández, C.; Álvarez, I. and De la Fuente, J. 2011. Nutritional and sensory aspects of light lamb meat enriched in $n$ - 3 fatty acids during refrigerated storage. Food Chemistry 124:147-155. https://doi.org/10.1016/j.foodchem.2010.05.117

Garcia, P. T.; Pordomingo, A.; Perez, C. D.; Rios, M. D.; Sancho, A. M.; Volpi Lagreca, G. and Casal, J. J. 2016. Influence of cultivar and cutting date on the fatty acid composition of forage crops for grazing beef production in Argentina. Grass and Forage Science 71:235-244. https://doi.org/10.1111/gfs.12167

González-Calvo, L.; Ripoll, G.; Molino, F.; Calvo, J. H. and Joy, M. 2015. The relationship between muscle $\alpha$-tocopherol concentration and meat oxidation in light lambs fed vitamin E supplements prior to slaughter. Journal of the Science of Food and Agriculture 95:103-110. https://doi.org/10.1002/jsfa.6688

Hajji, H.; Joy, M.; Ripoll, G.; Smeti, S.; Mekki, I.; Molino Gahete, F.; Mahouachi, M. and Atti, N. 2016. Meat physicochemical properties, fatty acid profile, lipid oxidation and sensory characteristics from three North African lamb breeds, as influenced by concentrate or pasture finishing diets. Journal of Food Composition and Analysis 48:102-110. https://doi. org/10.1016/j.jfca.2016.02.011

Hopkins, D. L.; Lamb, T. A.; Kerr, M. J.; van de Ven, R. J. and Ponnampalam, E. N. 2013. Examination of the effect of ageing and temperature at rigor on colour stability of lamb meat. Meat Science 95:311-316.

Ítavo, L. C. V.; de Souza, A. D. V.; Fávaro, S. P.; Ítavo, C. C. B. F.; Petit, H. V.; Dias, A. M.; Morais, M. G.; Coelho, R. G.; Reis, F. A.; Costa, J. A. A. and Roscoe, R. 2016. Intake, digestibility, performance, carcass characteristics and meat quality of lambs fed different levels of crambe meal in the diet. Animal Feed Science and Technology 216:40-48. https://doi.org/10.1016/j. anifeedsci.2016.02.015

Jose, C. G.; Jacob, R. H.; Pethick, D. W. and Gardner, G. E. 2016. Short term supplementation rates to optimise vitamin E concentration for retail colour stability of Australian lamb meat. Meat Science 111:101-109. https://doi.org/10.1016/j. meatsci.2015.08.006

Kasapidou, E.; Enser, M.; Wood, J. D.; Richardson, R. I.; Wilkinson, R. G. and Sinclair, L. A. 2009. Influence of vitamin E supplementation and basal diet on the vitamin E status, performance and tissue fatty acid concentration in lambs. Animal 3:516-526. https://doi.org/10.1017/S1751731108003820

Kasapidou, E.; Wood, J. D.; Richardson, R. I.; Sinclair, L. A.; Wilkinson, R. G. and Enser, M. 2012. Effect of vitamin E supplementation and diet on fatty acid composition and on meat colour and lipid oxidation of lamb leg steaks displayed in modified atmosphere packs. Meat Science 90:908-916. https://doi.org/10.1016/j.meatsci.2011.11.031

Lee, J. H.; Waller, J. C.; Yilmaz, Y. and Melton, S. L. 2007. Effect of feeding rumen-protected dietary protein-oil supplements on fatty acid composition and $\alpha$-tocopherol content of blood serum and muscle lipids of lambs. Small Ruminant Research 72:101-110. https://doi.org/10.1016/j.smallrumres.2006.08.012

Liu, K.; Ge, S.; Luo, H.; Yue, D. and Yan, L. 2013. Effects of dietary vitamin E on muscle vitamin E and fatty acid content in Aohan fine-wool sheep. Journal of Animal Science and Biotechnology 4:21. https://doi.org/10.1186/2049-1891-4-21

Lobo, V.; Patil, A.; Phatak, A. and Chandra, N. 2010. Free radicals, antioxidants and functional foods: Impact on human health. Pharmacognosy Reviews 4:118-126. https://doi.org/10.4103/0973-7847.70902

Lobón, S.; Sanz, A.; Blanco, M.; Ripoll, G. and Joy, M. 2017. The type of forage and condensed tannins in dams' diet: Influence on meat shelf life of their suckling lambs. Small Ruminant Research 154:115-122. https://doi.org/10.1016/j. smallrumres.2017.08.005

Luciano, G.; Monahan, F. J.; Vasta, V.; Pennisi, P.; Bella, M. and Priolo, A. 2009. Lipid and colour stability of meat from lambs fed fresh herbage or concentrate. Meat Science 82:193-199. https://doi.org/10.1016/j.meatsci.2009.01.010

Luzia, D. M. M. and Jorge, N. 2009. Atividade antioxidante do extrato de sementes de limão (Citrus limon) adicionado ao óleo de soja em teste de estocagem acelerada. Química Nova 32:946-949. https://doi.org/10.1590/S010040422009000400022

Mapiye, C.; Dugan, M. E. R.; Juárez, M.; Basarab, J. A.; Baron, V. S.; Turner, T.; Yang, X.; Aldai, N. and Aalhus, J. L. 2012. Influence of $\alpha$-tocopherol supplementation on trans-18:1 and conjugated linoleic acid profiles in beef from steers fed a barley-based diet. Animal 6:1888-1896. https://doi.org/10.1017/S1751731112000730

Milewski, S.; Purwin, C.; Pysera, B.; Lipiński, K.; Antoszkiewicz, Z.; Sobiech, P.; Ząbek, K.; Fijałkowska, M.; Tański, Z. and Illek, J. 2014. Effect of feeding silages from different plant raw materials on the profile of fatty acids, cholesterol, and vitamins A and E in lamb meat. Acta Veterinaria Brno 83:371-378. https://doi.org/10.2754/avb201483040371 
Moher, D.; Liberati, A.; Tetzlaff, J. and Altman, D. G. (Prisma Group). 2009. Preferred reporting items for systematic reviews and meta-analyses: the PRISMA statement. PLoS Medicine 6(7):e1000097. https://doi.org/10.1371/journal. pmed.1000097

Morán, L.; Giráldez, F. J.; Panseri, S.; Aldai, N.; Jordán, M.; Chiesa, L. M. and Andrés, S. 2013. Effect of dietary carnosic acid on the fatty acid profile and flavour stability of meat from fattening lambs. Food Chemistry 138:2407-2414. https://doi. org/10.1016/j.foodchem.2012.12.033

Morán, L.; Rodríguez-Calleja, J. M.; Bodas, R.; Prieto, N.; Giráldez, F. J. and Andrés, S. 2012a. Carnosic acid dietary supplementation at $0.12 \%$ rates slows down meat discoloration in gluteus medius of fattening lambs. Meat Science 90:789-795. https://doi.org/10.1016/j.meatsci.2011.11.016

Morán, L.; Andrés, S.; Bodas, R.; Prieto, N. and Giráldez, F. J. 2012b. Meat texture and antioxidant status are improved when carnosic acid is included in the diet of fattening lambs. Meat Science 91:430-434. https://doi.org/10.1016/j. meatsci.2012.02.027

Muela, E.; Alonso, V.; Campo, M. M.; Sañudo, C. and Beltrán, J. A. 2014. Antioxidant diet supplementation and lamb quality throughout preservation time. Meat Science 98:289-295. https://doi.org/10.1016/j.meatsci.2014.05.035

Muíño, I.; Apeleo, E.; de la Fuente, J.; Pérez-Santaescolástica, C.; Rivas-Cañedo, A.; Pérez, C.; Díaz, M. T.; Cañeque, V. and Lauzurica, S. 2014. Effect of dietary supplementation with red wine extract or vitamin E, in combination with linseed and fish oil, on lamb meat quality. Meat Science 98:116-123. https://doi.org/10.1016/j.meatsci.2014.05.009

Ortuño, J.; Serrano, R. and Bañón, S. 2015. Antioxidant and antimicrobial effects of dietary supplementation with rosemary diterpenes (carnosic acid and carnosol) vs vitamin $\mathrm{E}$ on lamb meat packed under protective atmosphere. Meat Science 110:62-69. https://doi.org/10.1016/j.meatsci.2015.07.011

Papuc, C.; Goran, G. V.; Predescu, C. N. and Nicorescu, V. 2017. Mechanisms of oxidative processes in meat and toxicity induced by postprandial degradation products: A review. Comprehensive Reviews in Food Science and Food Safety 16:96-123. https://doi.org/10.1111/1541-4337.12241

Perlo, F.; Bonato, P.; Teira, G.; Tisocco, O.; Vicentin, J.; Pueyo, J. and Mansilla, A. 2008. Meat quality of lambs produced in the Mesopotamia region of Argentina finished on different diets. Meat Science 79:576-581. https://doi.org/10.1016/j. meatsci.2007.10.005

Petron, M. J.; Raes, K.; Claeys, E.; Lourenço, M.; Fremaut, D. and De Smet, S. 2007. Effect of grazing pastures of different botanical composition on antioxidant enzyme activities and oxidative stability of lamb meat. Meat Science 75:737-745. https://doi.org/10.1016/j.meatsci.2006.10.010

Ponnampalam, E. N.; Burnett, V. F.; Norng, S.; Hopkins, D. L.; Plozza, T. and Jacobs, J. L. 2016. Muscle antioxidant (vitamin E) and major fatty acid groups, lipid oxidation and retail colour of meat from lambs fed a roughage based diet with flaxseed or algae. Meat Science 111:154-160. https://doi.org/10.1016/j.meatsci.2015.09.007

Ponnampalam, E. N.; Burnett, V. F.; Norng, S.; Warner, R. D. and Jacobs, J. L. 2012a. Vitamin E and fatty acid content of lamb meat from perennial pasture or annual pasture systems with supplements. Animal Production Science 52:255-262. https://doi.org/10.1071/AN11054

Ponnampalam, E. N.; Butler, K. L.; McDonagh, M. B.; Jacobs, J. L. and Hopkins, D. 2012b. Relationship between muscle antioxidant status, forms of iron, polyunsaturated fatty acids and functionality (retail colour) of meat in lambs. Meat Science 90:297-303. https://doi.org/10.1016/j.meatsci.2011.07.014

Popova, T.; Gonzales-Barron, U. and Cadavez, V. 2015. A meta-analysis of the effect of pasture access on the lipid content and fatty acid composition of lamb meat. Food Research International 77:476-483. https://doi.org/10.1016/j. foodres.2015.08.020

Ripoll, G.; González-Calvo, L.; Molino, F.; Calvo, J. H. and Joy, M. 2013. Effects of finishing period length with vitamin E supplementation and alfalfa grazing on carcass color and the evolution of meat color and the lipid oxidation of light lambs. Meat Science 93:906-913. https://doi.org/10.1016/j.meatsci.2012.09.017

Ripoll, G.; Joy, M. and Muñoz, F. 2011. Use of dietary vitamin E and selenium (Se) to increase the shelf life of modified atmosphere packaged light lamb meat. Meat Science 87:88-93. https://doi.org/10.1016/j.meatsci.2010.09.008

Sales, R. O.; Silva Sobrinho, A. G.; Zeola, N. M. B. L.; Lima, N. L. L.; Manzi, G. M.; Almeida, F. A. and Endo, V. 2013. Fresh and matured lamb meat quality fed with sunflower seeds and vitamin E. Ciência Rural 43:151-157.

Salter, B. and Tapper, T. 2013. The State and Higher Education: State \& Higher Educ. Routledge. 2 Park Square, Milton Park, Ablngdou, Omn 0X14 4RN 711 Third Avenue, New York, NY, 10017.

Simitzis, P. E.; Ilias-Dimopoulos, V.; Charismiadou, M. A.; Biniari, E. E. and Deligeorgis, S. G. 2013. The effects of dietary hesperidin supplementation on lamb performance and meat characteristics. Animal Science Journal 84:136-143. https://doi.org/10.1111/j.1740-0929.2012.01049.x

Simopoulos, A. P. 2002. The importance of the ratio of omega-6/omega-3 essential fatty acids. Biomedicine \& Pharmacotherapy 56:365-379.

Turner, K. E.; McClure, K. E.; Weiss, W. P.; Borton, R. J. and Foster, J. G. 2002. Alpha-tocopherol concentrations and case life of lamb muscle as influenced by concentrate or pasture finishing. Journal of Animal Science 80:2513-2521. 
Vieira, C.; Fernández-Diez, A.; Mateo, J.; Bodas, R.; Soto, S. and Manso, T. 2012. Effects of addition of different vegetable oils to lactating dairy ewes' diet on meat quality characteristics of suckling lambs reared on the ewes' milk. Meat Science 91:277-283. https://doi.org/10.1016/j.meatsci.2012.02.003

Wood, J. D.; Enser, M.; Fisher, A. V.; Nute, G. R.; Sheard, P. R.; Richardson, R. I.; Hughes, S. I. and Whittington, F. M. 2008. Fat deposition, fatty acid composition and meat quality: A review. Meat Science 78:343-358. https://doi.org/10.1016/j. meatsci.2007.07.019

Yagoubi, Y.; Joy, M.; Ripoll, G.; Mahouachi, M.; Bertolín, J. R. and Atti, N. 2018. Rosemary distillation residues reduce lipid oxidation, increase alpha-tocopherol content and improve fatty acid profile of lamb meat. Meat Science 136:23-29. https://doi.org/10.1016/j.meatsci.2017.10.007 